KINGA KUSZAK

Uniwersytet im. Adama Mickiewicza

w Poznaniu

\title{
POWAŻNA ROLA NIEPOWAŻNYCH RYMOWANEK. ZABAWA (GRA) SŁOWNA W LITERATURZE DLA DZIECI - JEJ WARTOŚĆ EDUKACYJNA
}

\begin{abstract}
Kuszak Kinga, Poważna rola niepoważnych rymowanek. Zabawa (gra) stowna w literaturze dla dzieci - jej wartość edukacyjna [The Serious Role of Silly Rhymes. Word Games (Plays) in Children's Literature and their Educational Value]. Studia Edukacyjne nr 40, 2016, Poznań 2016, pp. 89-112. Adam Mickiewicz University Press. ISSN 1233-6688. DOI: 10.14746/se.2016.40.6

The author tackles the subject of children's literature, described by Jerzy Cieślikowski as "children's folklore". Her area of interest centres mainly around poetry addressed to children, which is considered the closest form of literature to this age group. Poetry refers to forms of activity natural for children: rhythmic movement, rhyming, singing, creating new words, asking questions, etc. The article points to the educational role of language games (plays) in poetry, which both answer children's natural developmental needs and stimulate their linguistic competencies. The first part of the article discusses the sources of language play in poetry. The author highlights the role of the works of Jan Brzechwa and Julian Tuwim, who in the 1930s were the first to employ word play, unconventional use of idioms and proverbs, and nonsensical linguistic associations. They became a source of inspiration for contemporary children's poets. The paper further analyses selected poems whose common feature is the use of language games not only to entertain but to educate and inspire creativity. The poems were divided into the following categories: poems-plays on sounds (letters), poems-plays on rhyme and rhythm, poems-plays on words, poems-plays on idioms and proverbs, poems-questions and poems-associations. The conclusion points to the role of adults as guides in the world of poetry for children and their role in preparing children to receive and understand the message of poetry.
\end{abstract}

Key words: children's literature, poetry, preschool age, games, word play, developing child's linguistic competencies

\section{Wprowadzenie}

Często podkreśla się, że w XXI wieku literatura dla dzieci mierzy się z koniecznością konkurowania z „łatwymi” formami rozrywki, niewymaga- 
jącymi sposobami spędzania czasu. Rywalizuje $\mathrm{z}$ atrakcyjnymi formami wspierającymi proces uczenia się, których atrakcyjność

wynika z rozmaitości bodźców oddziałujących na użytkownika (ruchomość obrazu, kolorystyka, efekty świetlne i dźwiękowe) powodując szybkie ,zaprzyjaźnienie się” nawet niedoświadczonego odbiorcy $\mathrm{z}$ "modnymi mediami" ${ }^{1}$.

Zwraca się uwagę, iż literaturę dostosowuje się do kanonów obowiązujących w mediach, czyniąc ją wizualną, operującą obrazami zaczerpniętymi z rzeczywistości medialnej, z ograniczoną warstwą językową, operującą trywialnym i wulgarnym językiem. Do jej świata przenosi się popkulturowe wzory osobowe (np. serie papierowych gadżetów w formie komiksów do oglądania kolejnych wcieleń postaci z popularnych filmów animowanych, seriali itp.). Autorami tekstów dla najmłodszych zostają gwiazdy popkultury, które z wydawania kolejnych książek uczyniły element budowania własnego wizerunku medialnego. Tacy autorzy proponują najmłodszym „bestselery, które są sposobem autopromocji piszącego, mają się dobrze sprzedawać". Dla dzieci stają się rozrywką jednorazowego użytku, zostają szybko i bezrefleksyjnie przez nie "skonsumowane", a w ich miejsce pojawiają się kolejne książki-zabawki, książki-komiksy, książki-naklejanki, książki-wycinanki, książki-kolorowanki, bo jak podkreśla Z. Melosik „konsument ma dążyć do swojego szczęścia bez najmniejszego wahania i dążyć do >maksimum satysfakcji $<" 2$, a kultura popularna ma mu to zapewnić. Dziecko staje się więc konsumentem, a nie czytelnikiem, odbiorcą literackiego dzieła. Wśród pseudoliteratury umykają powszechnej uwadze pozycje wymagające wysiłku intelektualnego, które w mądry sposób łączą funkcję ludyczną - bawią, z funkcją dydaktyczną i artystyczną dzieła literackiego. Ignoruje się fakt, że przecież literatura dla dzieci to dziedzina twórczości literackiej, której cele i właściwości wyznaczone są przez zakres wiedzy życiowej i literackiej jej odbiorców ${ }^{3}$. Jej zadaniem jest bawić (ale nie w sposób trywialny), wywoływać refleksję, autentyczne przeżycie, ma skłaniać do namysłu nad światem, życiem ludzi, zwierząt itp. Sprzyja rozwijaniu szeroko rozumianych kompetencji jednostki, w tym kompetencji językowych, emocjonalnych, społecznych, poznawczych, twórczych itp.

${ }^{1}$ M. Centner-Guz, Kompetencje nauczycieli ksztatcenia zintegrowanego do ksztatcenia literackiego - wybrane problemy, [w:] System integralny w edukacji dziecka. Konteksty i konsekwencje zmian, red. H. Siwek, M. Bereźnicka, Warszawa 2011, s. 148.

2 Z. Melosik, Kultura popularna i tożsamość młodzieży. W niewoli władzy i wolności, Kraków 2013, s. 161.

${ }^{3}$ M. Głowiński i in., Stownik terminów literackich, Wrocław 2008, s. 283. 


\section{Zabawy (gry) słowne w literaturze dla dzieci}

Jerzy Cieślikowski pisząc o literaturze dla najmłodszych, ujął ją w szerszej kategorii folkloru dziecięcego, na który jego zdaniem składają się trzy typy utworów:

- pisane przez dorosłych dla dzieci, np. kołysanki, bajki;

- twory powstałe $\mathrm{w}$ wyniku adaptacji przez dzieci różnych elementów kultury dorosłych (np. gry, zabawy);

- twory produkowane przez same dzieci, do których można zaliczyć: wyliczanki, przezywanki, zamawianki (wywołanki), zgadywanki, wyzywanki, niebylice (wywracanki) i rymowanki (skakanki, śpiewanki, wykrzykanki, mruczanki) ${ }^{4}$.

W twórczości dla najmłodszych funkcjonują też inne odmiany strukturalno-formalne, jak: chowanka, gdybanka, klaskanka, zamawianka, pocieszanka, kołowanka ${ }^{5}$. Cechą literatury dla dzieci jest łączenie i wzajemne przenikanie się gatunków. Podkreśla się, że rygorystyczne rozgraniczenie gatunkowe tej literatury jest wręcz niemożliwe, gdyż cechuje ją synkretyzm, liczne modyfikacje związane zarówno z przekazem oralnym, jak i aktywnym - twórczym odbiorem przez dziecko ${ }^{6}$. Niezależnie od tendencji do współwystępowania gatunków, wyodrębnia się taką kategorię, jaką jest poezja. Zwraca się uwagę na jej źródła i podkreśla, że poezja dziecięca wywodzi się z kołysanki-śpiewanki. Jest najczęściej pierwszą formą kontaktu dziecka $z$ utworem wierszowanym. $Z$ czasem do tej pierwszej formy pisanej wierszem dołączyły takie odmiany, jak: patataje, wywracanki, przekomarzanki i przedrzeźnianki, przepychanki i przytulanki. W XIX wieku wiersze dla dzieci pełniły przede wszystkim funkcję dydaktyczną; ich twórcom zależało na wykorzystaniu łatwej do zapamiętania formy rymowanej $\mathrm{w}$ celu przekazywania treści.

Piszący rymopis posługiwał się rymem nie dla niego samego, nie dla wydobycia określonych efektów artystycznych, lecz w celu ułatwienia pamięciowego opanowania tekstu niosącego ważką treść dydaktyczną czy moralną7.

4 J. Cieślikowski, Literatura i podkultura dziecięca, Wrocław 1975, s. 76-78; Z. Adamczykowa, Literatura "czwarta" - w kręu zagadnień teoretycznych, [w:] Literatura dla dzieci i młodzieży (po roku 1980), red. K. Heska-Kwaśniewicz, Katowice 2008, s. 40.

5 Z. Adamczykowa Literatura "czwarta", s. 40-41.

6 Tamże, s. 41.

${ }^{7}$ R. Waksmund, Literatura pokoju dziecinnego, Warszawa 1986, s. 168. 
Stosunkowo najnowszym elementem poezji dziecięcej są liryki dziecię$\mathrm{ce}^{8}$, pełnią one przede wszystkim funkcję artystyczną. $\mathrm{W}$ takich utworach „nastrój i brzmienie utworu górują nad treścią, będącą pretekstem do snucia poetyckich impresji"9. Współczesna poezja dla dzieci łączy wszystkie te funkcje: bawi, uczy, przekazuje emocje, zachęca do ich uzewnętrzniania, stymuluje indywidualną wrażliwość, ma wartość artystyczną charakterystyczną dla dzieła literackiego. Alicja Baluch podkreśla, że poezja dla dzieci

powinna się odznaczać umiejętnościami odczuwania duszy dziecka, myślenia jego wyobrażeniami, mówienia jego językiem, zbieżnością z ludową piosenką, paralelizmem obrazów, magicznością motywów, animizacją, melodyjnością jako zasadą kompozycyjną, umiejętnością splatania realności z fantazją, optymizmem i pogodą ${ }^{10}$.

Zdaniem J. Cieślikowskiego, dorośli piszą utwory dla dzieci w celu ich zabawienia. Zabawa ma zaś charakter bardziej lub mniej doraźny i praktyczny ${ }^{11}$. Z kolei A. Baluch zauważa też, że przyjęcie postawy „błazeńskiej” $\mathrm{w}$ poezji dla dzieci pozwala dotrzeć do prawdziwych korzeni poezji. Podkreśla, że

z tej perspektywy dziecko staje się synonimem poety (poeta-dziecko, "poeta jak dziecko"). Dorosłość zaś może oznaczać utratę prawdziwej wrażliwości, daru tworzenia, stoczenia się $\mathrm{w}$ "prozę"12.

Do eksponowanych cech poezji zalicza się przejawy gry językowej, zabawę znaczeniami i formą słów, dowcip językowy, eksponowanie fonicznej strony języka13. Poezja ma bawić czytelnika (choć oczywiście nie tylko, gdyż podejmuje też sprawy poważne, trudne), a dzięki zaproszeniu do zabawy sprzyjać indywidualnemu uczeniu się. Szczególną grupę wśród zabawnych utworów kierowanych do dzieci stanowią wiersze lingwistyczne, którym chciałabym poświęcić ten artykuł. Do tej grupy utworów zalicza się „wierszyki łamiące języki” i „wierszyki rozwijające języki”14. W niniejszych rozważaniach chciałabym jednak rozszerzyć tę kategorię, proponując różne typy wierszy-zabaw stymulujących rozwój kompetencji językowych dziecka.

\footnotetext{
8 A. Baluch, Od form prostych do arcydzieła, Kraków 2008, s. 39.

${ }^{9}$ R. Waksmund, Literatura pokoju dziecinnego, s. 168.

10 A. Baluch, Od form prostych do arcydzieła, s. 41.

11 J. Cieślikowski, Literatura i podkultura dziecięca, s. 76.

12 Tamże, s. 95.

${ }_{13}$ M. Głowiński i in., Stownik terminów literackich, s. 283-284.

${ }_{14}$ D. Świerczyńska-Jelonek, G. Walczewska-Klimczak, Dziecko w dialogu z tekstem literackim, Warszawa 2015, s. 31-32.
} 


\section{Bawiąc-uczyć. Zabawy (gry) słowne w wybranych utworach dla najmłodszych}

Zabawy i gry słowne w literaturze dla najmłodszych zagościły dzięki twórczości Jana Brzechwy i Juliana Tuwima15. Jan Brzechwa opublikował pierwszy tomik poezji dla dzieci zatytułowany Tańcowała igła z nitka w 1937 roku. W 1939 roku wydał drugi tom pod tytułem Kaczka Dziwaczka. Pierwsze utwory, w których poeta „tradycyjne formy oddziaływania wychowawczego zastąpił humorem i ujęciem satyryczno-groteskowym"16 wywołały krytykę ze strony części pedagogów. Zarzucano mu zbyt dużo groteski i absurdalnego humoru („panie sumie, w sumie pan niewiele umie”), krytykowano, że posługuje się niezrozumiałą dla młodych czytelników grą słów („ślepy przeoczył", "głuchy streścił, co słyszał"), używa zbyt trudnych zwrotów, jak „besztać”, czy „pypeć”17. Lawinę krytyki wywołał wiersz zatytułowany „Nie pieprz Pietrze”, w którym „miał jakoby sugerować dzieciom inne, bardziej dosadne znaczenie czasownika >pieprzyć<" $<$ innym utworze, zdaniem recenzenta, „perfidnie podrzucał małym czytelnikom rym do słowa $>$ zupa $<$, przywodzący na myśl brzydkie słowo"18. Julian Tuwim pierwsze wiersze dla dzieci opublikował w roku 1936 na łamach „Wiadomości Literackich”. Najpierw ukazała się "Lokomotywa” i "Ptasie radio”, następnie „O słoniu bez pamięci”, bo taki właśnie tytuł nosił pierwotnie wiersz o słoniu Trąbalskim. W 1938 roku wydał aż cztery książeczki w utworami dla dzieci, zatytułowane: Lokomotywa, O panu Tralalińskim, Słoń Trąalski, Zosia Samosia $i$ inne wierszyki19. Entuzjastycznie wiersze przyjęła Janina Broniewska, zachwycając się "Lokomotywą" i „Ptasim radiem”. Inni krytycy dostrzegli w nich niebezpieczeństwo dla harmonijnego rozwoju młodego pokolenia. O „Słoniu Trąbalskim” pisano następująco: „książeczka niby wesoła, z miłymi ilustracjami, jakie lubią dzieci, ale wszystko po to, by tym bardziej perfidnie oddziaływać na dziecięce umysły" 20. Zdaniem krytyków, „Skakanka” wcale nie uczy dzieci ostrożności, wręcz przeciwnie - zachęca do nieposłuszeństwa wobec rodziców. „Wszak autor pisze, że dwadzieścia innych kózek od rana do wieczora skacze i nic im się złego nie stało"21.

15 Elementy humoru w literaturze dla dzieci dostrzega się już w utworach wcześniejszych autorów, np. u Marii Konopnickiej.

16 S. Frycie, I. Kaniowska-Lewańska, Kultura literacka w przedszkolu. Antologia, cz. II, Warszawa 1984, s. 232.

${ }_{17}$ M. Urbaniak, Brzechwa nie dla dzieci, Warszawa 2013, s. 93-95.

18 Tamże, s. 95.

${ }_{19}$ M. Urbanek Tuwim wylękniony bluźnierca, Warszawa 2013, s. 136.

20 Tamże, s. 138-139.

21 Tamże, s. 139. 
J. Cieślikowski analizując ten wiersz $\mathrm{w}$ drugiej połowie $\mathrm{XX}$ wieku podkreślał, że autor wykorzystał tu popularne przysłowie, jednak jest ono przysłowiem dziecięcym. Jego dziecięcość wyraża się „nie tylko od strony jego komunikatywnej prostoty, ale i języka" ${ }^{22}$. Narrator wiersza zdaniem Cieślikowskiego nie kwestionuje prawdy warstwy empirycznej, ale podważa jego prawdę emocjonalną. „Rzeczywiście, gdyby kózka nie skakała, to nogi by nie złamała. Ale co to za życie, jeżeli nie można poskakać" ${ }^{23}$. Zdaniem tego autora, J. Tuwim posługując się metaforą skaczącej kózki odzwierciedlił naturalną ruchliwość dziecka przedszkolnego.

Niezależnie od kontrowersji, jakie do dziś wywołują niektóre utwory Jana Brzechwy i Juliana Tuwima, wspomniani autorzy uznani zostali za „czarodziejów słowa" i wyznaczyli nową kategorię twórczości dla dzieci - zabawy (gry) językowe, a wymyślone przez nich powiedzenia na stałe znalazły się w zasobie słownikowym kolejnych pokoleń Polaków.

Te utwory po prostu są wokół nas i w nas samych, czy tego chcemy, czy nie - po prostu nas otaczają. Zapamiętane fragmenty powtarzają pradziadkowie, dziadkowie, rodzice i dzieci jako zabawne porzekadła - jednym chórem: „a to feler, westchnął seler", "panie chrzanie, niech pan przestanie”, „w Szczebrzeszynie chrząszcz brzmi w trzcinie i Szczebrzeszyn z tego słynie", "tańcowała igła z nitką, igła pięknie, nitka brzydko" 24 .

Zapoczątkowany przez J. Brzechwę i J. Tuwima nurt zabaw językowych w poezji dla dzieci, "gry w destrukcje, w wywracanie, w sytuacje na opak" 25 kontynuowali i kontynuują tacy poeci, jak Ludwik Jerzy Kern, Wanda Chotomska, Danuta Wawiłow, Agnieszka Frączek, Małgorzata Strzałkowska, Marcin Brykczyński, Natalia Usenko i inni. Ich cechą wspólną jest zrozumienie prawidłowości potrzeb rozwojowych odbiorców; rozumieją oni, że dziecko chce się bawić, a zabawowy charakter dziecięcej aktywności przejawia się w:

1) dialogowości - dziecko uprawia gry, bawi się, wyraża siebie w rzeczywistym lub wyobrażonym kontakcie z innymi;

2) zdolności do wyobrażania sobie fikcyjnych światów;

3) postawie radości wyrażającej się w estetyce karnawału;

4) różnych rodzajach komizmu - od sytuacyjnego do językowego ${ }^{26}$.

22 J. Cieślikowski, Literatura i podkultura dziecięca, s. 184.

23 Tamże, s. 185.

${ }^{24}$ G. Leszczyński, Czarodziej stowa, [w:] Jan Brzechwa dzieciom, Warszawa 2011, s. 5.

${ }^{25}$ J. Cieślikowski, Literatura i podkultura dziecięca, s. 259.

26 Podaję za: H. Cybulska, Tekst poetycki jako inspiracja twórczości językowej dzieci, [w:] Problemy edukacji lingwistycznej. Ksztatcenie jezzyka ojczystego dziecka, t. 1, red. M.T. Michalewska, M. Kisiel, Kraków 2002, s. 119. 
Zachęcają więc najmłodszych do wspólnej zabawy, grają znaczeniami, zaskakują podobieństwem dźwięków i nietypowymi skojarzeniami. Proponują kalambury, zagadki słowne, wspólne rozszyfrowywanie znaczeń słów, zachęcają do namysłu nad słowem i jego znaczeniem. W mądry sposób przekazują wiedzę sprzyjającą rozwijaniu kompetencji językowych i stymulują rozwój świadomości językowej najmłodszych. Ich cechą jest to, że nie pełnią jedynie funkcji zabawiania dziecka, ale ich

pełna czy bogata konkretyzacja może dopiero zaistnieć w wyniku aktywnego, twórczego, dopełniającego odbioru - w swoistej grze między autorem, jego dziełem a czytelnikiem [odbiorcą-do. K.K.]"27.

Wybierając wiersze-zabawy (gry) językowe i dokonując ich analizy, kategorią nadrzędną uczyniłam kategorię zabawy językowej, rozumianej jako swoista żartobliwa, przepełniona humorem, wspólnym śmiechem, interakcja między poetą a dzieckiem $\mathrm{i}$ uporządkowałam $\mathrm{w}$ następujące podkategorie.

\section{Wiersze-zabawy głoską (literą) ${ }^{28}$}

Zabawy głoską (literą) to grupa rymowanek, których celem jest skoncentrowanie uwagi odbiorcy na określonej głosce (literze). Można tu wyodrębnić następujące działania proponowane młodemu odbiorcy:

- głoska (litera) staje się motywem przewodnim wiersza, a utwór jest tak skomponowany, by wiodąca głoska (litera) występowała w każdym słowie. Tak czyni Małgorzata Strzałkowska w utworze „Królik”29:

„Kurkiem kranu kręci kruk,

Kroplą tranu brudząc bruk,

A przy kranie,

Robiąc pranie,

Królik gra na fortepianie"

Rymowanka została skonstruowana wokół motywu głoski (liter) „r”. Ze względu na powtarzający się motyw zawierający pewną trudność artykula-

27 J. Cieślikowski, Literatura osobna, Warszawa 1985, s. 64.

${ }^{28}$ Dokonuję rozróżnienia głoska-litera, gdyż głoska jest jednostką mowy, jej elementem dźwiękowym, zaś litera jest znakiem graficznym i nie musi odpowiadać głosce. Dzieci przedszkolne poznają i wyodrębniają głoski w procesie analizy słuchowej, litery poznają później $\mathrm{w}$ procesie analizy wzrokowej, na etapie nauki czytania.

${ }^{29}$ M. Strzałkowska, Wierszyki tamiące języki, Poznań 2006, s. 15. 
cyjną (głoska „r" pojawia się w mowie dziecka około 5. roku życia), rymowanka może służyć stymulowaniu rozwoju artykulacji tej głoski.

Warto jednak zauważyć, że ma ona także inne walory. W wierszu dzięki słownej rymowance skojarzone zostały odległe od siebie obrazy: kapiącej wody, kruka, królika grającego na fortepianie, prania, by w efekcie stworzyć obraz nonsensowny ale zabawny, służący skoncentrowaniu uwagi dziecka na określonej głosce (literze);

- głoska (litera) zostaje zastąpiona przez inną głoskę (literę), co daje komiczny efekt nieprawidłowej, zaburzonej artykulacji. Taki zabieg zaproponował np. Konstanty Ildefons Gałczyński w wierszu „Strasna zaba”30:
„Pewna pani na Marsałkowskiej
Kupowała synkę z groskiem
W towarzystwie swego męza, ponurego draba;
Wchodzą do sklepu, pani w sloch,
W ksyk i w lament: -Męzu och!, och (...)".

Zdaniem A. Baluch, nie jest on utworem przeznaczonym dla dzieci, tylko "podejmującym estetykę dziecięcości”31. Można się w tej kwestii zgodzić, jednak warto dostrzec, że atmosfera żartu, ironia utworu mogą zostać przez dzieci pod koniec wieku przedszkolnego odczytane zgodnie z intencją autora. Warto nadmienić, że tego typu rymowanki zwracają uwagę dziecka na istnienie normy artykulacyjnej i odpowiadają poziomowi świadomości językowej dziecka w tym okresie rozwoju. Istnieją dowody na to, że dziecko przedszkolne odkrywając normę staje się jej „strażnikiem”, co przejawia się tendencją do hiperpoprawności, autokorekty własnej, błędnej wypowiedzi, korygowania niepoprawnych pod względem artykulacyjnym wypowiedzi rówieśników i dorosłych ${ }^{32}$ itp.

Dostrzegając zainteresowanie dziecka normą artykulacyjną, także inni autorzy proponują zabawę $\mathrm{w}$ jej świadome przekraczanie - bawią się normą i jej naruszeniem. Tak robi Wanda Chotomska w wierszu „Kłopoty z R”33, tworząc substytucje głoski i odkrywając przed dzieckiem słowa powstałe w wyniku zamiany głoski ",r" na ",1":

„Był sobie kiedyś chłopiec Julek,

Co nie wymawiał "r” w ogóle.

Gdy się pytano tego Julka:

${ }^{30}$ K.I. Gałczyński, Wiersze dla dzieci, Poznań 2010, s. 24.

31 A. Baluch, Od form prostych do arcydzieła, s. 99.

32 K. Kuszak, Przejawy rozwoju świadomości językowej w okresie dzieciństwa i możliwości jej stymulowania, [w:] Cieszyński Almanach Pedagogiczny, t. 3, Katowice 2014, s. 119-120.

33 W. Chotomska, W kraju patataju, Warszawa 2014, s. 32. 
-Kto znosi jajka?

Mówił: -Kulka (...)".

Autorka koncentruje uwagę dziecka na znaczeniu wyrazów różniących się jedną cechą dystynktywną. Pomaga mu dostrzec, że zmiana jednego dźwięku (jednej głoski) zmienia sens wyrazu: „kurka” staje się „,kulką", , Jurek" - „Julkiem";

- głoska (litera) ma zainspirować dzieci do zabaw dźwiękonaśladowczych, jak w wierszu „Koza” Natalii Usenko ${ }^{34}$ :

„Stoi koza po pas w trawie.

Aż nie widać kozy prawie!

Me-e-e-e-e-e!

Stoi smutna, zaryczana.

Czemu płace?

Bo gdzie indziej paść się

Chce-e-e-e-e-e!

Bo tak kozie się wydaje,

Że daleko są gdzieś kraje,

Gdzie-e-e-e-e-e! (...)".

Tego typu rymowanki zwane są też wierszami onomatopeicznymi 35 . Jednym z bardziej znanych i kunsztownych utworów jest „Ptasie radio” Juliana Tuwima:

„(...) Halo! O, halo lo lo lo lo!

Tu tu tu tu tu tu tu

Radio, radijo, dijo, ijo, ijo,

Tuijo, trijo, tru, lu, lu, lu, lu

Pio, pio, pijo, lo, lo, lo, lo, lo,

Plo, plo, plo, plo, lo, hlo! (...)".

Dziecko zachęcone przez autora podejmuje zabawy dźwiękonaśladowcze i dzięki działaniu doświadcza np. różnicy między samogłoską a spółgłoską. Odkrywa, choć oczywiście nie uświadamia sobie tego, że głoski są artykułowane dzięki specyficznemu ułożeniu narządów artykulacyjnych: warg, języka, podniebienia miękkiego itp. Każda głoska ma inne miejsce artykulacji. Łączy ze sobą w różnych układach sylab, sztucznych wyrazów-logotomów, głoski o odległych miejscach artykulacji, bawi się wybrzmiewanymi dźwiękami. Takie propozycje literackie „wyzwalają żywe w reakcjach dzieci poczucie humoru"36, nie tylko bawią, zachęcają do zabaw w naśladowanie

\footnotetext{
${ }^{34}$ N. Usenko, Kot, który patrzyt na księżyc, Łódź 2012, s. 9.

${ }^{35}$ R. Waksmund, Poezja dla dzieci. Antologia form i tematów, Wrocław 1987, s. 212.

${ }^{36}$ S. Frycie, I. Kaniowska-Lewańska, Kultura literacka w przedszkolu, s. 214.
} 
różnych dźwięków, ale też sprzyjają doskonaleniu sprawności artykulacyjnej i wspierają rozwój słuchu fonematycznego. W okresie przedszkolnym dzieci przechodzą następujące fazy rozwoju tej sprawności: od identyfikowania głosek realizowanych ze znaczną starannością przez dorosłych, przez spostrzeganie głosek i różnic między głoskami należącymi do tej samej grupy, do automatyzacji i doskonalenia słuchu fonologicznego (do rozpoznawania i identyfikacji głosek wystarczą tylko niektóre ich cechy lub kontury ${ }^{37}$ ). Badania sugerują, że dzieci w wieku 4-6 lat, które mają wysoko rozwinięte umiejętności fonologiczne, jak: wykrywanie fonemów, sylab, rymów, szybciej opanowują umiejętność czytania i biegle czytają w porównaniu z rówieśnikami, którzy mają niższe umiejętności fonologiczne ${ }^{38}$;

- głoski (litery) przedstawione są jako elementy zbioru zwanego alfabetem ${ }^{39}$, jak w wierszu Danuty Wawiłow „Alfabet" 40 :

„A - to jest właśnie Alfabet,

Który za chwilę poznacie.

B - to jest Bednarz Barnaba,

Mój bardzo dobry przyjaciel.

C - to jest córka piekarza,

Ma parę różowych warkoczy (...)".

W tym przypadku wierszowane zabawy zachęcają dzieci do przedstawiania własnych propozycji wyrazów rozpoczynających się określoną głoską (literą alfabetu). Zabieg substytucji polega na tym, że w strukturę rytmiczną wiersza dzieci same mogą wprowadzić kolejne nazwy (w tym przypadku odnoszące się do osób), zachowując odpowiednie rymy ${ }^{41}$. Wyodrębnianie $\mathrm{w}$ nagłosie głoski stanowi element działań służących przygotowaniu dziecka przedszkolnego do opanowania umiejętności czytania i pisania. Takie zabawy wykorzystujące aktywne słuchanie i produkcję dźwięków stanowią też "przeciwwagę" dla nadmiernej stymulacji współczesnego dziecka obrazami ${ }^{42}$.

37 J. Porayski-Pomsta, O rozwoju mowy dziecka dwa studia, Warszawa 2015, s. 137.

${ }^{38}$ D.R. Schaffer, K. Kipp, Psychologia rozwoju od dziecka do dorosłości, Gdańsk 2012, s. 401.

39 Zaliczane do kategorii wierszy abecadłowych, patrz: R. Waksumund, Poezja dla dzieci, s. 131-136. Jednak nie wszystkie zaprezentowane przez R. Waksmunda utwory można zaliczyć do zabaw językowych.

40 D. Wawiłow, Danuta Wawiłow dzieciom, Warszawa 2013, s. 151.

${ }^{41}$ Przykład takiej zabawy podaje D. Dobrowolska, Metodyka edukacji polonistycznej w okresie wczesnoszkolnym, Kraków 2015, s. 179.

42 J. Cieszyńska, M. Korendo, Wczesna interwencja terapeutyczna. Stymulacja rozwoju dziecka od noworodka do 6 roku życia, Kraków 2008, s. 150. 


\section{Wiersze-zabawy rymem i rytmem}

Jerzy Cieślikowski we wstępie do Antologii poezji dziecięcej podkreśla, że dzieci lubią rymować, a analizując ich spontaniczną twórczość, znajdziemy wiele takich rymowanych tekstów, zwanych rymowankami ${ }^{43}$. Właśnie na wiek przedszkolny przypada okres szczególnego zainteresowania rymowaniem, co uzewnętrznia się w formie tzw. ekikików, czyli wierszy motorycznych, opartych na ruchowym działaniu dziecka ${ }^{44}$. Dziecko łączy wówczas naturalną potrzebę poszukiwania rymów z rytmem i ruchem. Rymowanki zaś rodzą się z samej radości rymowania i dobierania słów, które się rymują. Kornel Czukowski przytacza zupełnie pozbawione sensów znaczeniowych układy logatomów, np.: „Kunda, munda, karamunda. Dunda, bunda, paramunda" 45 . Z kolei Hanna Krauze-Sikorska prezentuje następującą rymowankę: "trele morele, rele wmele. Dada barada, kada marada. Tuda ruda, karabuda" 46 . Podkreśla przy tym, że dobieranie rymów do wiersza jest dla dziecka zawsze działalnością oryginalną i wymaga jego uwagi i zaangażowania.

Równie chętnie jak tworzy, dziecko słucha utworów o wyraźnym rytmie i współbrzmieniu słów w rymach. Rytm w utworach poetyckich modeluje sposób ich przedstawiania (czytania, recytowania), determinuje pojawianie się obrazów w wyobraźni odbiorcy i wzmacnia sugestywność oddziaływania ${ }^{47}$. Taką inspirującą zabawę rymami proponuje najmłodszym Joanna Papuzińska w rymowance zatytułowanej „Na wędrówkę" 48 :

„Oto jest piosenka letnia,

Ona jest na drogę świetna,

W każdym się plecaku zmieści

Więc ją na wędrówkę bierzcie!

Wędrówka, drówka, rówka, ówka, wka, ka, a! (...)

Wyruszamy z domu rano,

Zanim jeszcze wszyscy wstaną,

Odpoczniemy sobie potem,

$\mathrm{Na}$ zielonej łące wśród stokrotek.

Stokrotka, krotka, rotka, otka, tka, ka, a! (...)".

${ }^{43}$ J. Cieślikowski, Antologia poezji dziecięcej, s. VIII.

${ }^{44}$ A. Baluch, Dziecko i świat przedstawiony, czyli tajemnice dziecięcej lektury, Warszawa 1987, s. 22.

45 Za: J. Cieślikowski, Literatura i podkultura dziecięca, s. 129.

${ }^{46} \mathrm{H}$. Krauze-Sikorska, Edukacja przez sztukę. O edukacyjnych wartościach artystycznej twórczości dziecka, Poznań 2006, s. 71.

47 E. Mikoś, Rytm jako wykładnik podmiotowości. O doświadczeniach lekturowych dziecka [w:] O tym, co Alicja odkryła... W kregu badań nad toposem dzieciństwa i literatura dla dzieci i młodzieży, red. A. Ungeheuer-Gołąb, M. Chrobak, M. Rogoża, Kraków 2015, s. 368.

${ }^{48}$ J. Papuzińska, Rozwesotki, Poznań 2008, s. 12-13. 
Przedstawiona powyżej propozycja to przykład tzw. śpiewanki. Można ją rytmicznie wypowiedzieć, można ją też zaśpiewać i zatańczyć, choć rymy nie powstały na zasadzie oczywistych, prostych skojarzeń, czego przykładem jest choćby para: „potem-stokrotek”. Autorka proponuje rymy trudniejsze, ale "wpadające w ucho". Cechą charakterystyczną śpiewanki jest jej refren. W tym przypadku również nieoczywisty, za każdym razem inny, choć tworzony na tej samej zasadzie poprzez odejmowanie głosek (liter) na początku wyrazu. Ten zabieg językowy bawi dziecko, zachęca do modyfikacji innych wyrazów, według zasady zaproponowanej przez poetkę. Zdaniem A. Ungeheuer-Gołąb, dzięki rymom w poezji dla dzieci można usłyszeć „tupot nóg, odczuwa się taneczny wir, wymachiwanie rękami i oszołomienie. Ruch prowokuje dźwięk, a dźwięk słowo ${ }^{49}$. W tym przypadku rymy i rytm nadają utworowi charakter wiersza, który sprzyja wędrówce, słychać w nim rytm kroków. Rymy pozwalają dzieciom, że łatwiej zapamiętają utwór i będą go prezentować, a zachęcone również improwizować na jego temat.

Inaczej bawi rymem Józef Ratajczak w utworze „Rym” 50 :

„Taki rym:

Cym.

Cym to sowo do rymu,

Które teraz brzmi: Cymu

i z każdym nowym rymem

Cym, Cymu-staje się cymem.

Rym sam się z cymem rymuje,

Bo Cyma wciąż potrzebuje (...)".

W zaprezentowanym przykładzie autor do pary dobiera neologizm, które w warstwie brzmieniowej odpowiadają słowu wyjściowemu: „rym”. Wykorzystuje skojarzenie oczywiste dla najmłodszych, bo funkcjonujące w wyliczankach typu „rym-cym-cym”. Działanie rymów w tym przypadku „polega na zaostrzeniu wyrazistości układów brzmieniowych i znaczeniowych (semantycznych), na całej przestrzeni wiersza"51. Warto nadmienić, że zdolność wychwycenia rymów przez dziecko stymuluje rozwój fonologiczny „poprzez rozpoznanie, że dwa słowa się rymują, nawet jeśli dziecko nie potrafi powiedzieć dokładnie, jaki dźwięk te słowa wspólnie posiadają"52.

${ }^{49}$ A. Ungeheuer-Gołąb, Rozwój kontaktów małego dziecka w literaturą, Warszawa 2011, s. 52.

50 J. Ratajczak, Wiersze dla dzieci, Wrocław 2000, s. 41.

51 D. Dobrowolska, Metodyka edukacji polonistycznej w okresie wczesnoszkolnym, Kraków 2015, s. 177.

52 M. Molicka, Rola rymowanek i piosenek w stymulacji świadomości fonologicznej w nauczaniu dzieci języka angielskiego, [w:] Edukacja dziecka. Mity i fakty, red. E. Jaszczyszyn, J. SzadaBorzyszkowska, Białystok 2010, s. 545. 
Dostępne badania sugerują ponadto, że $25 \%$ dzieci trzyletnich wyodrębnia rymy, a dzieci cztero- i pięcioletnie wyczuwają rymy i aliteracje ${ }^{53}$.

\section{Wiersze-zabawy słowem}

Ta grupa zabaw powstała z przekonania, że dziecko jest zainteresowane słowem, pyta o słowa dotychczas mu nieznane i samo tworzy nowe słowa na zasadzie analogii fleksyjnej, przenosi znane słowa z jednych kontekstów znaczeniowych do innych. „W wynalazczości językowej dziecka przeważają formy tworzenia form rzeczowych od czasowników lub odwrotnie, dokonanych na podstawie analogii $w$ sposób zupełnie prawidłowy"54. Ponieważ dziecko dość wcześnie opanowuje podstawy języka, dysponuje wiedzą słowotwórczą, jak podkreśla J. Cieślikowski, w sposób odważny „równy czynności poety" ${ }^{\prime \prime 5}$. Współcześni poeci odpowiadają na to zainteresowanie dziecka na kilka sposobów:

- odkrywając przed dziećmi słowa ukryte w innych słowach, jak czyni to Agnieszka Frączek w wierszu Śledź mnie śledzi"56:

„Śledź mi spędza z powiek sen.

Śmie mnie ŚLEDZIĆ, nicpoń ten!

Ściga mnie jak cień dzień w dzień,

Nawet się nie chowa, leń,

Tylko śmiga po chodnikach

I mi śmiało fotki cyka (...)".

W podobny sposób zachęca czytelników do poszukiwania słów ukrytych w słowach Ludwik Jerzy Kern w wierszu „Stonóżka z Pimpifluszek” 57:

„(...) W takiej szkole dla Stonóżek

Wymagania są dość duże.

Ci nie weźmiesz,

Byle co,

Wszystko musi być na STO.

Każdy matołek

Musi wiedzieć, co to STOłek.

Każda trzpiotka

Musi wiedzieć, co to STOkrotka.

53 Tamże.

54 J. Cieślikowski, Wielka zabawa, Wrocław 1985, s. 230.

55 Tamże.

56 A. Frączek, Zbaranieć można, Łódź 2016, s. 12.

57 L.J. Kern, Ludwik Jerzy Kern dzieciom, s. 21-22. 


\section{Każde lenisko}

Musi wiedzieć, co to STOisko.

Każda uczennica

Musi wiedzieć, co to STOlnica

I w ogóle przez cały rok

Nic, tylko STOnka,

STOp, STOs, STOk (...)".

Przedstawione jako przykład wiersze to wiersze-rebusy. Odkrywanie słów zawartych w innych słowach ułatwia dziecku warstwa graficzna, co jest charakterystyczne dla takiej formy zabawy, nieco zbliżonej $w$ formie do tzw. wierszy obrazkowych. Wyrazy zostały tak zapisane, by dziecko mogło wykorzystywać bodźce wzrokowe i słuchowe do odkrywania ukrytych słów;

- eksponując słowa, które mają jedno brzmienie, ale różne znaczenia. Zabawę homonimami, polisemami i homofonami ${ }^{58}$ proponuje Urszula Kozłowska w zbiorze Czapka nie Witka czyli odlotowe zabawy stowem, z którego pochodzi rymowanka "Stacz" ${ }^{59}$ :

„Staś to taka dziwna postać,

Która lubi sobie postać.

Odkąd rankiem z łóżka wstanie,

Cały dzień tak stać jest w stanie.

Tak mu świetnie to wychodzi,

Że nie chętnie gdzieś wychodzi (...)".

Tytuł utworu jest neologizmem słowotwórczym utworzonym dla potrzeb tekstu od czasownika "stać". Motywuje dziecko do poszukiwania odpowiedzi, kim jest „stacz”, co robi, jak się zachowuje itp. Wymyślone słowo oddziałuje na dziecięcą wyobraźnię i stymuluje do opowiadania o tym, co sobie wyobraziło. Ta zabawa $\mathrm{w}$ wyobrażanie została połączona $\mathrm{z}$ zabawą w poszukiwanie w tekście słów o różnych znaczeniach;

- przywołując archaizmy i/lub słowa rzadko używane, co proponuje Agnieszka Frączek w zbiorze zatytułowanym Banialuki do zabawy $i$ nauki i bawiąc się skojarzeniami, jakie te słowa wywołują:

„Kociokwik

- słówko wielce tajemnicze,

Bo czy koty mogą kwiczeć?

${ }^{58} \mathrm{~W}$ literaturze podkreśla się, że zjawisko polisemii i homonimii trudno niekiedy odróżnić dla potrzeb zabaw językowych z najmłodszymi i dokonywanie takich szczegółowych rozróżnień nie jest konieczne.

${ }_{59}$ U. Kozłowska, Czapka nie Witka, czyli odlotowe zabawy słowem, Rzeszów 2012, s. 11. 
Zwykle miałczą, lecz to jasne.

Czasem ten lub tamten wrzaśnie.

Gdy na niego nikt nie zerka,

To zaćwierka do wróbelka.

Kichnie,

Prychnie

Lub zamruczy.

Nawet szczekać się nauczy.

A Kot w Butach przecież gada!

Ale kwiczeć? Nie wypada".

Poetka nie tylko bawi się skojarzeniami związanymi ze słowem „kociokwik”, ale w sposób obrazowy wyjaśnia czytelnikom znaczenie: „Kocikwik ma niewiele wspólnego z kotem, a tym bardziej z kwikiem. No, chyba, że tych kotów jest pięćdziesiąt sześć i wszystkie naraz zaczną miauczeć. Kwiczeć nie muszą. I bez tego powstanie niezłe zamieszanie, chaos i bałagan. Jednym słowem: „kociokwik! Miau!"60;

- proponując czytanie słów „na opak”, jak w utworze „Kapoan” proponuje Joanna Papuzińska61:

„Był sobie chłopiec Szamot,

Bo dziwnie mówił tak,

Kapoan, czyli wspak.

Musiała sobie mama

Raz po raz głowę łamać

Nad tym co znaczy apuz,

Res, akłup i kełepus (...)

Ten utwór to literacka oferta odpowiadająca dziecięcej potrzebie posługiwania się językiem sekretnym. Charakteryzuje się on tym, że dzieci odkrywając umowność kodu językowego, wymyślają własny kod służący komunikowaniu, którego zasada przekazywana jest tylko członkom własnej grupy;

- tworząc neologizmy. Takie działanie proponuje np. Joanna Kulmowa w utworze „Pan Przekorneliusz"62. Imię tytułowego bohatera - Przekorneliusz jest neologizmem powstałym od przymiotnika "przekorny" lub rzeczownika "przekora”; w ten sposób poetka sugeruje cechy charakteru bohatera wiersza. Neologizm został utworzony w sposób analogiczny, jak czynią to dzieci. Zdaniem Heleny Synowiec, dzieci przedszkolne tworzą neologizmy $\mathrm{w}$ ramach następujących kategorii: nazwy wykonawców czynności

\footnotetext{
60 Tamże, s. 7.

61 J. Papuzińska, Rozwesołki.

62 J. Kulmowa, Kolory, Warszawa 2014, s. 49.
} 
(podobnie jak w wierszu „Stacz"), np. ten kto coś komuś zabiera - zabieracz, nazwy narzędzi, np. nabieraczka, nazwy miejsc, np. kajakarnia - przystań kajakowa ${ }^{63}$. Można więc powiedzieć, że źródło imienia bohatera utworu jest dla dzieci łatwe do interpretacji i odpowiada ich umiejętnościom słowotwórczym:

„Gdyby tak wierzyć plotkom

- To pan Przekorneliusz Złotko

Najchętniej włazi w błotko.

I nigdy się nie nuży

Nurzaniem w byle kałuży.

Wcale go nie wzrusza,

Że bywa przemoknięty

od pięty

do kapelusza $(\ldots)^{\prime \prime}$.

Przekorny bohater utworu „nie nuży się nurzaniem w kałuży”. Czytelnik otrzymuje nie tylko zabawę neologizmem, ale też propozycję zabawy homofonami - słowami o jednakowym brzmieniu, różniącymi się pisownią i odległym znaczeniu, a także etymologii. Ma też okazję ${ }^{64}$, by zastanowić się, na ile substytucja jednego dźwięku w wyrazie, jednej głoski (litery) zmienia jego znaczenie. Zostaje zachęcony do poszukiwania analogicznych par wyrazów.

\section{Wiersze-zabawy związkami frazeologicznymi i przysłowiami ${ }^{65}$}

Po funkcjonujące $\mathrm{w}$ świadomości zbiorowej przysłowia i powiedzenia sięgał Jan Brzechwa i to on wyznaczył kierunek rozwoju tej grupy wierszy. Jako pierwszy „wyjmował z pamięci i z mowy potocznej przysłowia, które układają się w metaforę i ściągają w elipsę, i odkrywał oraz racjonalizował ich przenośność", sprawdzał jakby mechanizm ich metaforyczności, tak jak robią to dzieci, gdy sprawdzają dosłownie np. powiedzenie "skocz na jednej nodze". Brzechwa odbiera przysłowiu jego mądrość i tworzy sylogizm logicznego myślenia. Rozbraja je z genetycznej i naturalnej mu poetyczności,

${ }^{63} \mathrm{H}$. Synowiec, Uczeń wśród związków frazeologicznych i regionalnych odmian polszczyzny, [w:] Dziecko w świecie języka, red. D. Bula, D. Krzyżyk, B. Niesporek-Szamburska, H. Synowiec, Kraków 2004, s. 134-135.

${ }^{64} \mathrm{Na}$ ten aspekt zwracałam uwagę w odniesieniu do wiersza Wandy Chotomskiej.

65 Wybór związków frazeologicznych i przysłów w utworach dla dzieci zamieszczono $\mathrm{w}$ pozycji K. Kuszak, Świat związów frazeologicznych w języku dziecka. Inspiracje praktyczne badania - implikacje praktyczne, Poznań 2014, s. 179-205. 
która z biegiem czasu starła się i spowszedniała, i przez przewrotną weryfikację poetycką nadawał mu nową osobliwość, niezwyczajność, zatrzymując uwagę wyobraźni i języka"66. W ten sposób bawią się przysłowiami i związkami frazeologicznymi współcześni poeci, a wśród nich Agnieszka Frączek, np. w utworze „Grzęda" 67:

„W całym bloku słychać kłótnie:

- Nie ma mowy! Absolutnie!

Jeśli pójdę spać z kurami,

Jutro będę niewyspany!

To ten Antek, smyk z parteru,

Krzyczy w drodze ze spaceru.

- Mogę spać naprawdę wszędzie,

Tylko - proszę! - nie na grzędzie".

Poznając zabawne rymowanki, dzieci mają okazję dostrzec i zrozumieć związek frazeologiczny w szerszym kontekście. Na tej podstawie mogą podjąć próbę wyjaśnienia jego metaforycznego znaczenia, które nie jest sumą znaczeń poszczególnych słów. Otrzymują też od autorki podpowiedź, jak należy zinterpretować znaczenie tego powiedzenia.

Marcin Brykczyński gromadzi związki frazeologiczne koncentrujące się wokół wybranego motywu przewodniego, np. oka, ognia, zegara itp. i tworzy na ten temat żartobliwe rymowanki, jak w utworze "Gołym okiem"68:

„Raz okulista pewien w Sanoku,

Który pacjentów wciąż miał na oku,

Idąc ulicą wpadł komuś w oko,

Chociaż niechcący, ale głęboko.

Fakt ten nikogo nie mógł zaskoczyć,

Bo już z daleka rzucał się w oczy,

Więc kto kłopotów nie miał ze wzrokiem,

Ten mógł zobaczyć to gołym okiem (...)".

Agnieszka Frączek z właściwym sobie poczuciem humoru zaprasza dzieci w świat przysłów w wierszu zatytułowanym „Ptaszysko czyli lepszy wróbel w garści niż gołąb na dachu"69 i wyjaśnia znaczenie popularnego powiedzenia:

„U pana Leszka

Ptaszysko mieszka.

${ }^{66} \mathrm{~J}$. Cieślikowski, Antologia poezji dziecięcej, s. XXIX.

${ }^{67}$ A. Frączek, Siano w głowie, czyli trafita kosa na idiom, Łódź 2013.

68 M. Brykczyński, Z deszczu pod rynnę, czyli jeszcze raz o wyrażeniach, które pokazuja język, Łódź 2012, s. 16-17; tegoż: Ni pies, ni wydra, czyli o wyrażeniach, które pokazuja język, Łódź 2012.

${ }^{69}$ A. Frączek, Gdy przy stowie jest przystowie, Łódź 2012, s. 34-35. 
Nie jest kolorowym pawiem

(choć Lech twierdzi, że jest .... PRAWIE)

I nie gada tak jak ara

(ale się podobno stara),

Nie ma w sobie nic z kanarka

(może prócz wymiarów w barkach)

Czy gołębia z dachu obok.

Kim ptaszysko jest?

Jest sobą.

Czyli?

Wróblem. Szarym, małym...

Według Leszka - doskonałym.

Co w tym ptaszku niezwykłego...?

Nic prócz faktu, że jest jego".

Tego typu wiersze rozwijają wiedzę dziecka na temat związków frazeologicznych oraz przysłów i mogą stanowić element „kąpieli frazeologicznej"70. Inspirują do posługiwania się utrwalonymi w tradycji i kulturze powiedzeniami, co potwierdzają wyniki badań B. Bonieckiej, iż dzieci przedszkolne „rozpoznają tak znaczenie dosłowne, jak i przenośne i potrafią je błyskotliwie, inteligentnie użyć"71. Badania K. Kuszak wskazują z kolei, że dzieci pod koniec wieku przedszkolnego intepretują popularne powiedzenia przez pryzmat własnych doświadczeń. Nie dostrzegają ich szerszego kontekstu znaczeniowego, dokonują interpretacji intuicyjnych, skupiając swoją uwagę na wybranym słowie (słowach), wokół którego koncentrują swoją wypowiedź. Interpretacje związków frazeologicznych w ujęciu dzieci sześcioletnich są interpretacjami dosłownymi, nie ujmującymi ukrytego znaczenia powiedzenia, do jego znaczenia wyrażonego nie wprost. Część dzieci odkrywa znaczenie przenośne niektórych związków frazeologicznych i potrafi je wyjaśnićp 72 .

\section{Wiersze-pytania}

Wiersze-pytania, zwane też wierszami zagadkowymi, można pogrupować na zapytanki, zgadywanki i zagadki poetyckie ${ }^{73}$. Odwołują się do pytań formułowanych przez dziecko w tzw. okresie pytań, który przypada na etap

${ }^{70}$ K. Kuszak, Świat związków frazeologicznych.

71 B. Boniecka, Dziecięce wyobrażenie świata, Lublin 2010, s. 94.

72 K. Kuszak, Sześciolatek w świecie związków frazeologicznych, Nauczanie Początkowe, Kształcenie Zintegrowane, 2015/2016, 2.

${ }^{73}$ Z. Adamczykowa, Literatura dziecięca. Funkcje - kategorie - gatunki, Warszawa 2004, s. $122-123$. 
między 2. a 4/5. rokiem życia. W tym czasie dzieci chcą zrozumieć, co i jak się dzieje; nieustannie zastanawiają się nad światem i "pozostają w stanie skutecznego zdziwienia, które otwiera perspektywy na oryginalne przeżywanie świata i kultury”74. Pytania zadawane przez najmłodszych „stanowią doskonały materiał poetycki, z którego dorośli czerpią pomysły do własnych wierszy układanych dla dzieci"75. Mogą czynić to w sposób poważny, refleksyjny, ale mogą też formułować pytania w sposób wywołujący rozbawienie czytelnika. Przykładem może być wiersz Ludwika Jerzego Kerna „Na kanapie”76:

$$
\begin{aligned}
& \text { „Kto to chrapie } \\
& \text { Na kanapie? } \\
& \text { Kto się w ucho } \\
& \text { Przez sen drapie? } \\
& \text { Kto, gdy zły } \\
& \text { Szczerzy kły? } \\
& \text { Kogo czasem } \\
& \text { Gryzą pchły? (....)”. }
\end{aligned}
$$

Poeta wciąga dziecko w dialog, zadaje pytania, na które może ono poszukać odpowiedzi. Dziecko może też sformułować własne pytania, zgodnie z tym co je zastanawia i zadziwia w otaczającym świecie.

Nieco inną zabawę w pytania proponuje Joanna Papuzińska w rymowance „Wół"77:

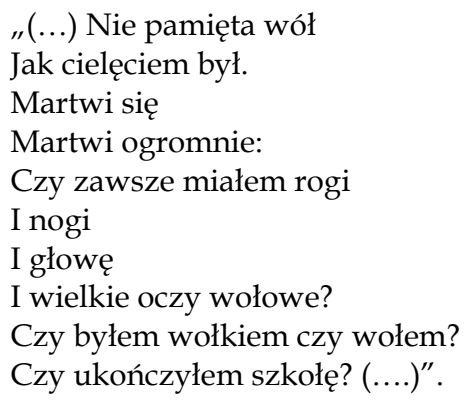

Jest to przykład utworu, w którym poetka wykorzystując zabawną formę, stawia pytania ważne dla dziecka: Co było wcześniej? Jaki byłem, jak byłem bardzo mały? Jacy byli moi rodzice, gdy byli mali? Gdzie byłem, gdy

${ }^{74}$ U. Chęcińska, Edukacja kulturalna matego dziecka. Joanny Kulmowej pajdologia poetycka in extenso [w:] Children in the Postmodern World. Culture-Media-Social Inequality, red. H. KrauzeSikorska, M. Klichowski, A. Basińska, Poznań 2014, s. 279.

75 A. Baluch, Dziecko i świat przedstawiony, s. 80.

${ }^{76}$ L.J. Kern, Ludwik Jerzy Kern dzieciom, s. 153.

77 J. Papuzińska, Pan Przekorneliusz, Poznań 2005, s. 14. 
mnie jeszcze nie było? Wychodzi z założenia, że przecież dzieci „pytają nie tylko o to, co jest im fizycznie i psychicznie bliskie, ale także o te obszary rzeczywistości, które tradycyjnie uznawane były za niedostępne dla nich. Czynią to tym łatwiej, że ich myślenie wolne jest od licznych zniewalających przedzałożeń i presupozycji obecnych w myśleniu dorosłych"78.

Danuta Wawiłow zadaje pytania w nieco inny sposób. Utwór zatytułowany „Trudna zagadka"79, to zagadka poetycka:

„Tatuś, powiem ci zagadkę!

Na ulicy stoi klatka,

A $w$ tej klatce sobie siedzi

Bardzo dużo złych niedźwiedzi

I pilnuje klatki pies!

Zgadnij, tatuś, co to jest? (...)".

Ten wiersz stanowi przykład utworu napisanego z perspektywy dziecka kierującego pytanie $\mathrm{w}$ stronę dorosłego. Motywuje dzieci do zabawy $\mathrm{w}$ układanie podobnych absurdalnych pytań i do twórczej ekspresji językowej związanej z udzielaniem na nie odpowiedzi. Poetka zachęca do odkrycia sensu zagadki.

\section{Wiersze-skojarzenia}

Jerzy Cieślikowski opisując dziecięce umiejętności poetyzowania, przywołuje przykład dziewczynki, która widząc, jak matka ubiła puszystą pianę z białek, zawołała: ach, mamusiu, jaka ty jesteś pianistka! Jego zdaniem dziewczynka skojarzyła podobieństwo słów: piana-piano-pianino ${ }^{80}$. W sposób odpowiadający dziecięcemu rozumowaniu tworzą literackie skojarzenia poeci. Przykładem takich zabaw językowych jest utwór Wandy Chotomskiej „Konik morski" 81 . Autorka poprzez grę w skojarzenia zachęca młodych odbiorców do refleksji nad zwyczajami koników morskich:

„Skoro są morskie koniki

To wniosek $\mathrm{z}$ tego jest taki,

Że dzieci tych morskich koników

To chyba morskie źrebaki".

${ }_{78}$ M. Szczepska-Pustkowska, Jak polska szkoła uśmierca dziecięce filozoficzne zmagania ze światem, [w:] Wczesna edukacja. Między schematem a poszukiwaniem nowych ujęć teoretyczno-badawczych, red. D. Klus-Stańska, E. Szatan, D. Bronk, Gdańsk 2007, s. 100.

79 D. Wawiłow, Danuta Wawiłow dzieciom, s. 123.

80 J. Cieślikowski, Wielka zabawa, Wrocław 1985, s. 230.

${ }^{81}$ W. Chotomska, W kraju patataju, s. 32. 
W. Chotomska zachęca dzieci do zgłębiania wiedzy na temat życia tych morskich zwierząt. Posługuje się analogią, porównując życie koników morskich do bliższego doświadczeniom dzieci życia koni hodowlanych żyjących w stajni.

„(...) Kto wychowuje dzieci? - Tata.

Nie znają lejców ani bata,

Nie jedzą owsa ani siana,

Ich dieta nie jest wszystkim znana,

Lecz wiem, że preferują one

Żyjątka morskie mocno słone (...)".

Agnieszka Frączek w rymowance "Gafa” 82 również proponuje młodym czytelnikom zabawę w skojarzenia:

„(...) Widać, że przybył tu prosto z buszu!

Nikomu nawet się nie ukłonił,

Za to o zgrozo!, szafę ZASŁONIŁ.

Na jej pięć szuflad i na drzwi dwoje,

Na zgrabne sęki, rodowe słoje

Padł w jednej chwili słoniowy cień.

Teraz w odwecie, nocą w i dzień,

Szafa próbuje słonia... ZASZAFIĆ.

Lecz nie potrafi".

W tym utworze poetka rozpoczyna grę w kalambury, którą można kontynuować zestawiając nazwy różnych mebli znajdujących się w pomieszczeniu i nazwy różnych zwierząt. Takie działania rozwijają wyobraźnię, twórcze użycie języka.

\section{Podsumowanie}

Irena Adamek podkreśla, że aktywność podejmowana przez dziecko ma tylko wówczas znaczenie rozwojowe, kiedy: aktywności zewnętrznej i wewnętrznej towarzyszy intensywna praca umysłu, gdy pojawiają się różnorodne emocje i odczucia aktywność ma charakter rzeczywisty, a nie pozorowany, ma też charakter różnorodny, a dziecko może korzystać zarówno z zasobów wewnętrznych, jak i zewnętrznych ${ }^{83}$. Takiemu uczeniu sprzyja

82 A. Frączek, Zbaranieć można, Łódź 2016, s. 20.

83 I. Adamek, Zmiana paradygmatu edukacji dziecka - od nauczania do uczenia się. Wymagania stawiane wspótczesnej edukacji, [w:] Edukacja dziecka, s. 20. 
kontakt z poezją. Przywołam za Urszulą Chęcińską słowa Joanny Kulmowej, iż

literatura dla dzieci winna wprowadzać je w świat pełen przeżyć, niekonwencjonalnych postaw i zachowań, wobec których nigdy nie pozostaną obojętne. Poezja dla dzieci musi być najlepsza. Dlatego poeta dla dzieci powinien wypowiadać siebie dziecko wobec dziecka równie wrażliwego - z prostotą artystycznego wyrazu, ze świeżością treści i dbałością o oryginalność formy literackiej"84.

W poezji mamy więc potencjalnie wszystkie elementy sprzyjające aktywnemu uczeniu się dziecka, którego podstawą jest przeżycie. Wiek przedszkolny zwany jest etapem spontaniczności w odbiorze literatury. $\mathrm{W}$ tym okresie dziecko naturalnie i spontanicznie reaguje na recytowany lub wspólnie czytany tekst (dorosły czyta, dziecko śledzi wzrokiem tekst, ogląda ilustracje). Czytaniu (w trakcie i/lub po zakończeniu) towarzyszy rozmowa, zabawa, naśladowanie słów, zwrotów, wymyślanie słów, zabawy brzmieniem dźwięków, wspólne działanie, którego elementem są teksty (rymowane, ale niekoniecznie) proponowane przez dziecko i dorosłego, improwizacja ruchowa, śpiew, gra itp. Obcowanie przez dziecko z poezją wymaga obecności mądrego i wrażliwego pośrednika, który poprowadzi je przez świat poetyckich metafor i skrótów myślowych, który pomoże rozszyfrować poetycki język i „umożliwi dziecku dotarcie do sensów wierszy, do jądra poezji" ${ }^{85}$. Dorosły (rodzic, a przede wszystkim nauczyciel) musi zatem poezję dla dzieci czytać i rozumieć. Powinien też umieć wybierać spośród bogatej oferty wydawniczej to co rzeczywiście wartościowe, a nie tylko to co popularne. Powinien umieć rozróżnić propozycje wabiące jedynie barwnymi ilustracjami i tytułami zaczerpniętymi lub skopiowanymi ze świata mediów od tych, które są perełkami literackimi, mają wartość edukacyjną, służą estetycznemu przeżyciu, mądrej zabawie, które stanowią materiał pozwalający na "oswajanie" dziecka z poezją, na przygotowanie go do odbioru i interpretacji poezji (ale także literatury w ogóle) w okresie późniejszym.

\section{BIBLIOGRAFIA}

Adamczykowa Z., Literatura dziecięca. Funkcje - kategorie - gatunki, Wydawnictwo WSP TWP, Warszawa 2004.

${ }^{84}$ U. Chęcińska, Edukacja kulturalna małego dziecka, s. 267.

${ }^{85} \mathrm{Z}$. Adamczykowa, Ksztatcenie literackie w edukacji zintegrowanej (stan wspótczesny-propozycje), [w:] System integralny w edukacji dziecka, s. 143. 
Adamczykowa Z., Literatura "czwarta" - w kręgu zagadnień teoretycznych, [w:] Literatura dla dzieci i młodzieży (po roku 1980), red. K. Heska-Kwaśniewicz, Wydawnictwo Uniwersytetu Śląskiego, Katowice 2008.

Adamczykowa Z., Kształcenie literackie w edukacji zintegrowanej (stan wspótczesnypropozycje), [w:] System integralny w edukacji dziecka. Konteksty i konsekwencje zmian, red. H. Siwek, M. Bereźnicka, Wydawnictwo WSP TWP, Warszawa 2011.

Adamek I., Zmiana paradygmatu edukacji dziecka - od nauczania do uczenia się. Wymagania stawiane wspótczesnej edukacji, [w:] Edukacja dziecka. Mity i fakty, red. E. Jaszczyszyn, E. Szada-Borzyszkowska, Wydawnictwo Uniwersyteckie Trans Humana, Białystok 2010.

Baluch A., Dziecko i świat przedstawiony, czyli tajemnice dziecięcej lektury, Nasza Księgarnia, Warszawa 1987.

Baluch A., Od form prostych do arcydzieła, Wydawnictwo Naukowe Akademii Pedagogicznej, Kraków 2008.

Boniecka B., Dziecięce wyobrażenie świata, Wydawnictwo UMCS, Lublin 2010.

Brykczyński M., Ni pies, ni wydra, czyli o wyrażeniach, które pokazuja język, Wydawnictwo Literatura, Łódź 2012.

Brykczyński M., Z deszczu pod rynnę czyli jeszcze raz o wyrażeniach, które pokazuja język, Wydawnictwo Literatura, Łódź 2012.

Centner-Guz M., Kompetencje nauczycieli ksztatcenia zintegrowanego do ksztatcenia literackiego - wybrane problemy, [w:] System integralny w edukacji dziecka. Konteksty $i$ konsekwencje zmian, red. H. Siwek, M. Bereźnicka, Wydawnictwo WSP TWP, Warszawa 2011.

Chęcińska U., Edukacja kulturalna małego dziecka. Joanny Kulmowej pajdologia poetycka in extenso [w:] Children in the Postmodern World. Culture-Media-Social Inequality, red. H. Krauze-Sikorska, M. Klichowski, A. Basińska, Wydawnictwo Naukowe UAM, Poznań 2014.

Chotomska W., W kraju patataju, Wydawnictwo MUZA, Warszawa 2014.

Cieślikowski J., Literatura i podkultura dziecięca, Ossolineum, Wrocław 1975.

Cieślikowski J., Antologia poezji dziecięcej, Ossolineum, Wrocław 1980.

Cieślikowski J., Literatura osobna, Nasza Księgarnia, Warszawa 1985.

Cieślikowski J., Wielka zabawa, Ossolineum, Wrocław 1985.

Cieszyńska J., Korendo M., Wczesna interwencja terapeutyczna. Stymulacja rozwoju dziecka od noworodka do 6 roku życia, Wydawnictwo Edukacyjne, Kraków 2008.

Cybulska H., Tekst poetycki jako inspiracja twórczości językowej dzieci, [w:] Problemy edukacji lingwistycznej. Kształcenie języka ojczystego dziecka, t. 1, red. M.T. Michalewska, M. Kisiel, Oficyna Wydawnicza Impuls, Kraków 2002.

Dobrowolska D., Metodyka edukacji polonistycznej w okresie wczesnoszkolnym, Oficyna Wydawnicza Impuls, Kraków 2015.

Frączek A., Gdy przy stowie jest przysłowie, Wydawnictwo Literatura, Łódź 2012.

Frączek A., Siano w głowie czyli trafita kosa na idiom, Wydawnictwo Literatura, Łódź 2013.

Frączek A., Zbaranieć można, Wydawnictwo Literatura, Łódź 2016.

Frycie S., Kaniowska-Lewańska I., Kultura literacka w przedszkolu. Antologia, cz. II, WSiP, Warszawa 1984.

Gałczyński K.I., Wiersze dla dzieci, Wydawnictwo Zysk i S-ka, Poznań 2010.

Głowiński M., Kostkiewiczowa T., Okopień-Sławińska A., Sławiński J., Słownik terminów literackich, Ossolineum, Wrocław 2008.

Kern L.J., Ludwik Jerzy Kern dzieciom, Nasza Księgarnia, Warszawa 2012.

Kozłowska U., Czapka nie Witka czyli odlotowe zabawy słowem, Dreams, Rzeszów 2012. 
Krauze-Sikorska H., Edukacja przez sztukę. O edukacyjnych wartościach artystycznej twórczości dziecka, Wydawnictwo Naukowe UAM, Poznań 2006.

Kulmowa J., Kolory, Wydawnictwo MUZA, Warszawa 2014.

Kuszak K., Przejawy rozwoju świadomości językowej w okresie dzieciństwa i możliwości jej stymulowania, [w:] Cieszyński Almanach Pedagogiczny, t. 3, Uniwersytet Śląski, Katowice 2014.

Kuszak K., Świat związów frazeologicznych w języku dziecka. Inspiracje praktyczne - badania implikacje praktyczne, Wydawnictwo Naukowe UAM, Poznań 2014.

Kuszak K., Sześciolatek w świecie związków frazeologicznych, Zeszyty Kieleckie, Nauczanie Początkowe, Kształcenie Zintegrowane, 2015/2016, 2.

Leszczyński G., Czarodziej stowa, [w:] Jan Brzechwa dzieciom, Nasza Księgarnia, Warszawa 2011.

Melosik Z., Kultura popularna i tożsamość młodzieży. W niewoli władzy i wolności, Oficyna Wydawnicza Impuls, Kraków 2013.

Mikoś E., Rytm jako wykładnik podmiotowości. O doświadczeniach lekturowych dziecka [w:] O tym, co Alicja odkryła... W kręgu badan nad toposem dzieciństwa i literatura dla dzieci i młodzieży, red. A. Ungeheuer-Gołąb, M. Chrobak, M. Rogoża, Uniwersytet Pedagogiczny, Kraków 2015.

Molicka M., Rola rymowanek i piosenek w stymulacji świadomości fonologicznej w nauczaniu dzieci jezzyka angielskiego, [w:] Edukacja dziecka. Mity i fakty, red. E. Jaszczyszyn, J. Szada-Borzyszkowska, Wydawnictwo Uniwersyteckie Trans Humana, Białystok 2010.

Papuzińska J., Rozwesołki, Wydawnictwo Mila, Poznań 2008.

Papuzińska J., Pan Przekorneliusz, G\&P Oficyna Wydawnicza, Poznań 2005.

Porayski-Pomsta J., O rozwoju mowy dziecka dwa studia, Dom Wydawniczy Elipsa, Warszawa 2015.

Ratajczak J., Wiersze dla dzieci, Siedmioróg, Wrocław 2000.

Schaffer D.R., Kipp K., Psychologia rozwoju od dziecka do dorosłości, Harmonia Universitas, Gdańsk 2012.

Strzałkowska M., Wierszyki tamiące języki, Media Rodzina, Poznań 2006.

Synowiec H., Uczeń wśród związków frazeologicznych i regionalnych odmian polszczyzny, [w:] Dziecko w świecie języka, red. D. Bula, D. Krzyżyk, B. Niesporek-Szamburska, H. Synowiec, Oficyna Wydawnicza Impuls, Kraków 2004.

Szczepska-Pustkowska M., Jak polska szkoła uśmierca dziecięce filozoficzne zmagania ze światem, [w:] Wczesna edukacja. Między schematem a poszukiwaniem nowych ujęć teoretycznobadawczych, red. D. Klus-Stańska, E. Szatan, D. Bronk, Uniwersytet Gdański, Gdańsk 2007.

Świerczyńska-Jelonek D., Walczewska-Klimczak G., Dziecko w dialogu z tekstem literackim, Ośrodek Rozwoju Edukacji, Warszawa 2015.

Urbaniak M., Brzechwa nie dla dzieci, Wydawnictwo Iskry, Warszawa 2013.

Urbanek M., Tuwim wylękniony bluźnierca, Wydawnictwo Iskry, Warszawa 2013.

Ungeheuer-Gołąb A., Rozwój kontaktów matego dziecka w literatura, Wydawnictwo Stowarzyszenia Bibliotekarzy Polskich, Warszawa 2011.

Usenko N., Kot, który patrzył na księżyc, Wydawnictwo Literatura, Łódź 2012.

Waksmund R., Literatura pokoju dziecinnego, Nasza Księgarnia, Warszawa 1986.

Waksmund R., Poezja dla dzieci. Antologia form i tematów, Uniwersytet Wrocławski, Wrocław 1987.

Wawiłow D., Danuta Wawiłow dzieciom, Nasza Księgarnia, Warszawa 2013. 